\title{
Spatial variation and area definition of nutrient extraction by Marandu grass biomass
}

\section{Variação espacial e definição de zonas de extração de nutrientes pela fitomassa do capim-Marandu}

\author{
Sabino Pereira da Silva Neto $^{1 *}$; Antonio Clementino dos Santos ${ }^{2}$; \\ Raimundo Laerton de Lima Leite ${ }^{3}$; Emerson Alexandrino ${ }^{2}$; \\ José Neuman Miranda Neiva²; José Geraldo Donizetti dos Santos²; \\ José Expedito Cavalcante da Silva²
}

\begin{abstract}
Resumo
O objetivo foi quantificar, descrever e identificar zonas de extração de nutrientes pela fitomassa da Brachiaria brazantha cv. Marandu em sistemas de integração floresta-pasto em região de transição Cerrado-Amazônia sobre Neossolo Quartzarênico Órtico típico, por meio de técnicas de geoestatística, de análise de componentes principais e da lógica de agrupamento não hierárquica de fuzzy k-médias. As avaliações foram realizadas em dois sistemas de integração floresta-pasto originários da associação de Brachiaria brizantha cv. Marandu e vegetação nativa raleada com 50\% e 75\% (IFP-I e IFP-II, respectivamente) de sombreamento e em pastagem de Brachiaria brizantha cv. Marandu em monocultivo. Para cada tratamento foi demarcada uma área de $4.000 \mathrm{~m}^{2}(40 \times 100 \mathrm{~m})$ que continham 32 pontos de coleta dispostos em malha de $4 \times 25 \mathrm{~m}$. Em cada ponto previamente marcado nos tratamentos avaliados se estimou as taxas de alongamento de lâminas foliares, senescência foliar e de alongamento de colmo. Ao final de cada ciclo produtivo foram determinados nas lâminas foliares e no colmo os teores de nutrientes (N, P, K, Ca e Mg. A extração de nutrientes foi calculada em função das taxas de produção bruta de forragem, de acúmulo de forragem e de folhas. Zonas de extração de nutrientes minerais pela fitomassa da Brachiaria brizantha cv. Marandu são definidas utilizando-se técnicas de geoestatística, de análise de componentes principais e da lógica de agrupamento não hierárquica de fuzzy k-médias. Assim o uso desses procedimentos é viável na definição e delimitação de zonas homogêneas dentro e entre os sistemas de produção de gramínea estudados.

Palavras-chave: Agropecuária de precisão, análise componentes principais, geoestatística, krigagem ordinária, lógica fuzzy k-médias, manejo da pastagem
\end{abstract}

\begin{abstract}
The present study aimed to quantify, describe and identify areas of nutrient extraction by Brachiaria brizantha $\mathrm{cv}$. Marandu biomass in integrated forest-pasture systems from a Cerrado-Amazon transition region with Typic Quartzipsamment soil by using geostatistical techniques, principal components analysis and non-hierarchical fuzzy k-means clustering. The evaluations were conducted in two integrated forest-pasture systems from an association with Brachiaria brizantha $\mathrm{cv}$. Marandu and native
\end{abstract}

\footnotetext{
${ }^{1}$ Prof., Instituto Federal de Educação, Ciência e Tecnologia do Tocantins, Gurupi, TO, Brasil. E-mail: sabino.pereira@ifto.edu.br

2 Profs., Fundação Universidade Federal do Tocantins, Araguaína, TO, Brasil.E-mail: clementino@mail.uft.edu.br; e_alexandrino@ yahoo.com.br; araguaia2007@gmail.com; jgsanttos@gmail.com; jecs@uft.edu.br

3 Prof., Instituto Federal de Educação, Ciência e Tecnologia do Tocantins, Araguatins, TO, Brasil. E-mail: laerton.leite@ifto.edu.br

* Author for correspondence
} 
vegetation thinned with $50 \%$ and $75 \%$ (integrated forest production-I (IFP-I) and IFP-II, respectively) shading and in Brachiaria brizantha cv. Marandu monoculture. For each treatment, an area of 4,000 $\mathrm{m}^{2}(40 \times 100 \mathrm{~m})$ was demarcated containing 32 collection points arranged in a $4 \times 25 \mathrm{~m}$ mesh. At each point, the rates of leaf elongation, senescence and stem elongation were estimated. At the end of each production cycle, the nutrient content $(\mathrm{N}, \mathrm{P}, \mathrm{K}, \mathrm{Ca}$ and $\mathrm{Mg}$ ) was determined in the leaf blades and stem. The nutrient uptake was calculated according to the rates of gross forage production, forage accumulation and leaf accumulation. The nutrient extraction zones of Brachiaria brizantha cv. Marandu biomass were defined using geostatistical techniques, principal components analysis and non-hierarchical fuzzy k-means clustering. Thus, the use of these procedures is feasible for the definition and delimitation of homogeneous zones within and between the pasture production systems studied.

Key words: Geostatistics, fuzzy k-means clustering, ordinary kriging, pasture management, precision agriculture, principal components analysis

\section{Introduction}

Through the establishment of integrated systems, the presence of trees in pastures has brought numerous benefits to the production system, both in the recovery and sustainability of forage production and to aspects of economic importance (CARVALHO; BOTREL, 2002). It is known, however, that the presence of trees reduces the amount of sunlight reaching grasses growing under the canopies, which usually decreases the growth of understory plants (PACIULLO et al., 2011). However, changes promoted by trees can also improve the nutritional quality of the grass in pasture areas under their influence (SOUSA et al., 2007).

The reduction of light available to grasses growing under a canopy of trees affects morphogenetic aspects determining productivity, depending on both the forage species and shading level imposed by the associated tree species (PACIULLO et al., 2008). However, certain fodder exhibit phenotypic plasticity, which enables change to biochemical, physiological and morphological characteristics in response to environmental variation. The nature of that response usually determines the capacity of species to succeed under temporary or permanent environmental stress (DIAS-FILHO, 2002).

The observed changes in the nutritional quality and the biochemical, physiological and morphological characteristics of grasses grown in silvopastoral systems can also cause changes in the extraction and export rates of soil nutrients by the grass biomass. The withdrawal of nutrients can also vary with the spatial arrangement of the shading trees. These changes can alter the spatial variability of the pasture environment.

The heterogeneity of nutrient extraction rates must be known to generate new innovative technologies and/or processes that can be incorporated into pasture management practices so that the use of grass for fodder can be optimized. Thus, spatial analysis may emerge as an efficient tool that allows the interpretation of changes in the spatial variability caused by the presence of trees in the integrated forest-pasture environment.

The present study aimed to quantify, describe and identify areas of nutrient extraction by Brachiaria brizantha cv. Marandu biomass in integrated forestpasture systems from a Cerrado-Amazon transition region with Typic Quartzipsamment soil by using geostatistical techniques, principal components analysis (PCA) and non-hierarchical fuzzy k-means clustering.

\section{Materials and Methods}

The study areas were located on the ranch of the School of Veterinary Medicine and Animal Science of the Federal University of Tocantins, Araguaína Campus. According to the Köppen classification system, the regional climate is type Aw (warm moist), with a dry season from April to October, 
annual pluviometric rainfall values of $1,800 \mathrm{~mm}$ and average temperature of $28^{\circ} \mathrm{C}$. The soil of the site was classified as Typic Quartzipsamment soil, according to the Brazilian Soil Classification System (Sistema Brasileiro de Classificação de Solos - SiBCS) (EMBRAPA, 2006).

The evaluations were conducted in two integrated forest-pasture systems formed by association with Brachiaria brizantha cv. Marandu and native vegetation thinned with $50 \%$ and $75 \%$ shading (integrated forest production-I (IFP-I) and IFP-II, respectively) and in Brachiaria brizantha cv Marandu pasture monoculture (Mono). For each treatment, an area of 4,000 $\mathrm{m}^{2}(40 \times 100 \mathrm{~m})$ was demarcated containing 32 collection points arranged in a 4 x $25 \mathrm{~m}$ mesh.

The shading was adjusted in each studied area using the illuminance level (Lux) measured with the aid of a light meter (Instrutherm, model LD 200) in 32 equidistant points in each treatment in March, July and November 2009 as a baseline. Readings were obtained simultaneously in the forest and full sun between 8:00 and 10:00 am. After obtaining the shading values at the different equidistant points, contour maps were constructed using geostatistical techniques that allowed visualization of the shade variability in each study area. Thus, with the aid of this information, areas were thinned, and the average shade was set as evenly as possible in each site (Figure 1).

Figure 1. Contour maps of the spatial distribution of shade in integrated Marandu grass forest-pasture systems with $57.90 \%( \pm 5.09)$ and $71.81 \%( \pm 4.54)$ shading (IFP-I and IFP-II, respectively).

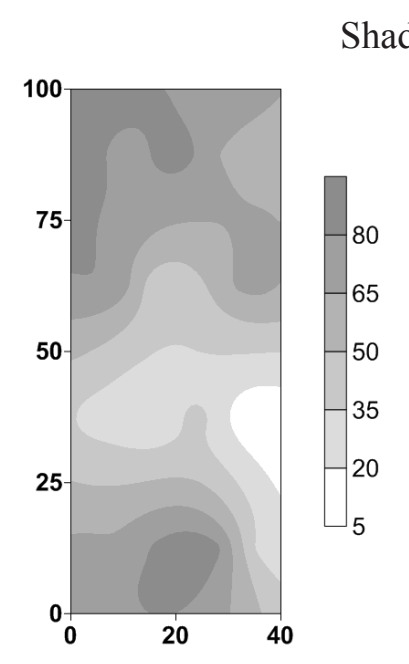

In December 2009 (before planting the Marandu grass), 1,500 $\mathrm{kg} \mathrm{ha}^{-1}$ of lime was applied. After application, the lime was incorporated into the soil by disk harrow in the grass monoculture, whereas in the IFP-I and IFP-II areas, incorporation was performed by hand. The Brachiaria brizantha cv. Marandu was sown in February 2010 at a rate of 6 $\mathrm{kg}$ of seed ha-1. Additionally, $70 \mathrm{~kg} \mathrm{ha}^{-1}$ of $\mathrm{P}_{2} \mathrm{O}_{5}$ in the form of superphosphate and $\mathrm{K}_{2} \mathrm{O}$ in the form of

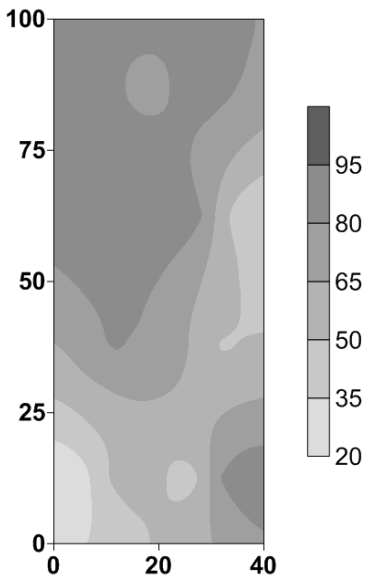

potassium chloride were applied.

At each point previously marked in the treatments, a tiller was identified to monitor the leaf appearance, elongation and senescence and stem elongation twice a week. From these data, the elongation rates of the leaf blades, leaf senescence and stem elongation were estimated and expressed in $\mathrm{mm} \mathrm{day}^{-1}$ tiller $^{-1}$. 
At the end of 28 days, at each point of the sampling grid, the forage mass contained in a rectangle of 1.0 $\mathrm{m} \times 0.5 \mathrm{~m}\left(0.5 \mathrm{~m}^{2}\right)$ was harvested to approximately $10 \mathrm{~cm}$ above ground level. At the same time, a tiller count was also performed to estimate the population density and the average weight of the tillers. Samples of emerging and opened leaf blades and stems were harvested at this time. These samples were subsequently measured, dried and weighed to establish the respective gravimetric factors ( $\mathrm{mg} \mathrm{mm}^{-}$ ${ }^{1}$ ). These estimates were used to transform the leaf elongation and stem data into their mass increases and senescence rate data into mass loss ( $\mathrm{mg}$ tiller ${ }^{-1}$ day $^{-1}$ ) (PONTES et al., 2003). These values were then used to estimate the gross production rate of forage (GPRFor), forage accumulation (ARFor) and leaf accumulation (ARLe).

At the end of each production cycle, the nutrient levels were determined in the leaf blade and stems. The content of nitrogen (N) was obtained by the Kjeldahl method, phosphorus (P) by photocolorimetry, potassium $(\mathrm{K})$ by flame photometry and calcium $(\mathrm{Ca})$ and magnesium $(\mathrm{Mg})$ by titration (EMBRAPA, 2005).

The extraction of nutrients on the basis of GPRFor, ARFor and ARLe was calculated by the following formula: Nutrient extracted $\left(\mathrm{kg} \mathrm{ha}^{-1}\right.$ day $^{-}$ $\left.{ }^{1}\right)=0.001 \times \mathrm{DM} \times \mathrm{NC}$, where DM $=$ dry matter in $\mathrm{kg} \mathrm{ha}{ }^{-1}$ from GPRFor, ARFor and ARLe; and $\mathrm{NC}=$ nutrient concentration in the plant, leaf blade and stem in $\mathrm{g} \mathrm{kg}^{-1}$.

Initially, exploratory analysis of the data collected in the areas studied was conducted to determine whether these events occur randomly or are aggregated by calculating the mean, median, minimum and maximum and the asymmetry coefficient, kurtosis and variation as well as the type of distribution. Kolmogorov-Smirnov tests at a 5\% significance level were used to test the normality hypothesis. The coefficient of variation (CV) limits proposed by Warrick and Nielsen (1980) were adopted to classify variability in the data; these limits are classified into low $(\mathrm{CV}<12 \%)$, medium $(12<\mathrm{CV}<60 \%)$ and high $(\mathrm{CV}>60 \%)$.

To statistically assess the areas, a multiple comparison of averages was performed using a nonparametric Kruskal-Wallis test at a 5\% significance level for the data sets that did not present normal distribution and Tukey's test at 5\% significance for normally distributed data. A comparison was made between treatments through the means found for each variable.

The pattern of spatial dependency was characterized by geostatistical analysis, calculating the semivariance with the equation proposed by Matheron (1963). Initially, visual fitting of the selected model to the point cloud of the experimental semivariogram was performed. The present study tested the semivariogram models: 1) spherical, 2) exponential and 3) Gaussian. The fit of the semivariograms provided the values of the nugget effect $\left(\mathrm{C}_{0}\right)$, range $(\mathrm{A})$ and the sill $(\mathrm{C}+\mathrm{C} 0)$ (VIEIRA, 2000). The nugget effect is the semivariance value at distance zero and represents the random variation component; the range is the maximum distance of spatial dependence and occurs where the sill is the value at which the curve of semivariance stabilizes to a constant value.

The selection of the fitted semivariogram model was based on minimizing the sum of squared residuals $\left(\mathrm{SS}_{\mathrm{r}}\right)$ and maximizing the multiple determination coefficient $\left(\mathrm{R}^{2}\right)$. In addition, the performance of each model was evaluated through the Akaike criterion (AIC). This criterion is given by the following equation: $\mathrm{AIC}=-2 \log (\mathrm{L})+$ $2 \mathrm{~K}$, where $\mathrm{L}$ is the maximized likelihood of the candidate model, and $\mathrm{K}$ is the number of parameters of the model in question.

To analyze the degree of spatial dependence (DSD), the ratio given by the following expression was used: $\mathrm{DSD}=\left[\mathrm{C} / \mathrm{C}+\mathrm{C}_{0}\right] \times 100$, which allows the classification of DSD in low spatial dependence 
(DSD $\leq 25 \%)$, moderate spatial dependence $(25 \%<$ DSD $\leq 75 \%)$ and strong spatial dependence (DSD $>$ 75\%) (ROBERTSON, 2008).

Interpolation of the values was performed by ordinary kriging to define the spatial pattern of variables in the areas, allowing the preparation of contour maps.

PCA was performed based on the correlation matrix between the components and the observed attributes to identify new variables that account for most of the variability, thus generating new values for each variable obtained by ordinary kriging corresponding to the main components. It was decided to select the major components whose eigenvalues were greater than one or with variance equal to or greater than 70\% (MARDIA, 1979). Through these techniques, it was possible to identify which variables best represent the characteristics of the area.

Grouping of the new variables from the selected principal components was obtained through the transformation of variables using non-hierarchical fuzzy k-means. The fuzzy exponent determines the degree of confusion or overlap between the various groups or clusters created. When $\varnothing=1$, the solution is divided, that is, there are well-defined clusters. When $\varnothing=\infty$, the solution has a high degree of confusion.

To determine the optimal number of units, the Fuzziness Performance Index (FPI) and the Modified Partition Entropy (MPE) were used. The optimal number of clusters of classes was then defined as one in which it minimizes the values of these two indices.

Analysis of variance (ANOVA) was used to check whether there were differences between the variable averages in the different zones generated from the cluster analysis. To compare the classes, Tukey's honest significant difference (HSD) test for samples of different sizes was used.

\section{Results and Discussion}

The gross production rate of forage (GPRFor) and the forage (ARFor) and leaf accumulation rates (ARLe) were influenced by the different shading conditions to which Marandu grass were exposed, with interaction between the shading level and the forage collection period (Table 1). During the first and second collection cycle, the grass grown in monoculture (Mono) had higher production rates than those of IFP, which did not differ. Nevertheless, the accumulation rates (GPRFor, ARFor and ARLe) in the grass monoculture decreased over time. In the IFP areas, the rate remained constant between evaluation cycles. Thus, in the third evaluation period, it was observed that the grass buildup rates no longer differed between the investigated areas.

Therefore, it was noted that the IFP systems managed to maintain steady growth of grass over the production cycles, possibly due to the incorporation of nutrients and increased soil microbial activity (XAVIER et al., 2003; NEVES et al., 2009). Furthermore, the shading and litter cover formed on the ground may have alleviated water stress, which reduced seasonality in the production of grass in IFP areas. Andrade et al. (2004) investigated the growth of Marandu grass under artificial shade and also observed that the seasonality of grass production may have been reduced due to shading.

The results presented in Table 2 show that the rate of extraction of nutrients in the grass biomass differed depending on the use. The monoculture of Marandu grass exported most nutrients in greater quantities. This situation was expected given that this area presented the highest average rates of biomass accumulation. The $\mathrm{N}$ extraction rates did not differ between the Mono and IFP-I areas. 
Table 1. Gross forage production rate (GPRFor), forage accumulation (ARFor) and leaf accumulation (ARLe) of Marandu grass monoculture (Mono) and integrated forest-pasture systems with 50 and $70 \%$ shading (IFP-I and IFPII, respectively).

\begin{tabular}{|c|c|c|c|c|}
\hline \multirow{2}{*}{ Location } & \multicolumn{3}{|c|}{ Cycle } & \multirow{2}{*}{ Mean } \\
\hline & $1^{\mathrm{o}}$ & $2^{\circ}$ & $3^{\circ}$ & \\
\hline \multicolumn{5}{|c|}{ GPRFor $\left(\mathrm{kg}\right.$ of $\mathrm{MS}^{2} \mathrm{ha}^{-1}$ day $\left.^{-1}\right)$} \\
\hline Mono & $120.03 \mathrm{aA}$ & $83.51 \mathrm{aB}$ & $55.78 \mathrm{aC}$ & $86.44 \mathrm{a}$ \\
\hline IFP-I & $72.75 \mathrm{bA}$ & $64.67 \mathrm{abA}$ & $57.16 \mathrm{aA}$ & $64.86 \mathrm{~b}$ \\
\hline IFP-II & $52.35 \mathrm{bA}$ & $44.19 \mathrm{bA}$ & $42.51 \mathrm{aA}$ & $46.35 \mathrm{c}$ \\
\hline Mean & $81.71 \mathrm{~A}$ & $64.12 \mathrm{~B}$ & $51.82 \mathrm{~B}$ & 65.88 \\
\hline \multicolumn{5}{|c|}{ ARFor (kg of DM ha- ${ }^{-1}$ day $\left.^{-1}\right)$} \\
\hline Mono & $107.85 \mathrm{aA}$ & $77.91 \mathrm{aB}$ & $46.06 \mathrm{aC}$ & $77.28 \mathrm{a}$ \\
\hline IFP-I & $61.81 \mathrm{bA}$ & $59.44 \mathrm{bA}$ & $56.56 \mathrm{aA}$ & $59.27 \mathrm{~b}$ \\
\hline IFP-II & $50.40 \mathrm{bA}$ & $42.35 \mathrm{bA}$ & $41.49 \mathrm{aA}$ & $44.90 \mathrm{c}$ \\
\hline Mean & $73.36 \mathrm{~A}$ & $59.90 \mathrm{~B}$ & $48.19 \mathrm{~B}$ & 60.48 \\
\hline \multicolumn{5}{|c|}{ ARLe $\left(\mathrm{kg}\right.$ of DM ha ${ }^{-1}$ day $\left.^{-1}\right)$} \\
\hline Mono & $95.93 \mathrm{aA}$ & $67.04 \mathrm{aB}$ & $39.37 \mathrm{aC}$ & $67.45 \mathrm{a}$ \\
\hline IFP-I & $46.70 \mathrm{bA}$ & $39.13 \mathrm{bA}$ & $43.91 \mathrm{aA}$ & $43.25 \mathrm{~b}$ \\
\hline IFP-II & $33.14 \mathrm{bA}$ & $28.62 \mathrm{bA}$ & $28.77 \mathrm{aA}$ & $30.17 \mathrm{c}$ \\
\hline Mean & $58.59 \mathrm{~A}$ & $44.93 \mathrm{~B}$ & $37.35 \mathrm{~B}$ & 46.96 \\
\hline
\end{tabular}

Means followed by the same letters (lowercase in the column and uppercase in the row) do not differ by Tukey's test at 5\% probability.

Table 2. Descriptive statistics of extraction rates of mineral nutrients (N, P, K, Ca and $\mathrm{Mg}$ ) by grass biomass in relation to the gross production rate of forage (GPRFor), stem accumulation (ARSt) and leaf accumulation (ARLe) and shading level in land use systems based on Marandu grass monoculture (Mono) and integrated Marandu grass forest-pasture with 50 and 70\% shading (IFP-I and IFP-II, respectively).

\begin{tabular}{|c|c|c|c|c|c|c|c|c|}
\hline \multirow{3}{*}{ Location } & \multirow{3}{*}{ Cycle means } & \multirow{3}{*}{$\operatorname{Med}^{1}$} & \multirow{3}{*}{$\operatorname{Min}^{2}$} & \multirow{3}{*}{$\operatorname{Max}^{3}$} & \multirow{2}{*}{\multicolumn{3}{|c|}{ Coefficient }} & \multirow{3}{*}{$\mathrm{KS}^{4} \mathrm{p}$-value } \\
\hline & & & & & & & & \\
\hline & & & & & Variance & Skewness & Kurtosis & \\
\hline \multicolumn{9}{|c|}{ N GPRFor $\left(\mathrm{kg}\right.$ of $\mathrm{N} \mathrm{ha}^{-1}$ day $\left.^{-1}\right)$} \\
\hline Mono & $1.09(0.06) \mathrm{ab}$ & 1.00 & 0.66 & 2.18 & 30.95 & 1.21 & 2.29 & $0.23^{*}$ \\
\hline IFP-I & $1.18(0.11) \mathrm{a}$ & 1.07 & 0.25 & 3.13 & 54.09 & 1.26 & 2.44 & $0.22^{*}$ \\
\hline IFP-II & $0.87(0.08) \mathrm{b}$ & 0.74 & 0.00 & 1.89 & 53.72 & 0.63 & -0.30 & $0.13^{*}$ \\
\hline \multicolumn{9}{|c|}{ N ARSt (kg of N ha-1 day $\left.^{-1}\right)$} \\
\hline Mono & $0.07(0.008) \mathrm{b}$ & 0.07 & 0.01 & 0.22 & 62.40 & 0.85 & 1.82 & $2 \times 10^{-7 * *}$ \\
\hline IFP-I & $0.20(0.02) \mathrm{a}$ & 0.20 & 0.02 & 0.57 & 62.60 & 1.02 & 1.78 & $0.17^{*}$ \\
\hline IFP-II & $0.18(0.02) \mathrm{a}$ & 0.19 & 0.00 & 0.40 & 51.40 & 0.34 & -0.66 & $0.71^{*}$ \\
\hline \multicolumn{9}{|c|}{ N ARLe $\left(\mathrm{kg}\right.$ of $\mathrm{N} \mathrm{ha}^{-1}$ day $\left.^{-1}\right)$} \\
\hline Mono & $1.20(0.08) \mathrm{a}$ & 1.11 & 0.56 & 2.80 & 38.51 & 1.33 & 3.05 & $0.41^{*}$ \\
\hline IFP-I & $1.04(0.11) \mathrm{ab}$ & 1.00 & 0.21 & 3.20 & 60.98 & 1.68 & 4.17 & $0.001^{* *}$ \\
\hline IFP-II & $0.75(0.08) \mathrm{b}$ & 0.60 & 0.00 & 1.72 & 59.29 & 0.78 & -0.39 & $0.005^{* *}$ \\
\hline \multicolumn{9}{|c|}{ P GPRFor $\left(\mathrm{kg}\right.$ of $\mathrm{P} \mathrm{ha}^{-1}$ day $\left.^{-1}\right)$} \\
\hline Mono & $0.53(0.04) \mathrm{a}$ & 0.53 & 0.25 & 1.28 & 42.20 & 1.12 & 2.24 & $0.53^{*}$ \\
\hline IFP-I & $0.30(0.03) \mathrm{b}$ & 0.28 & 0.06 & 0.87 & 55.66 & 1.48 & 3.33 & $0.02^{* *}$ \\
\hline IFP-II & $0.21(0.02) \mathrm{b}$ & 0.20 & 0.00 & 0.53 & 56.85 & 0.99 & 0.80 & $0.12^{*}$ \\
\hline
\end{tabular}


.. Continuation

\begin{tabular}{|c|c|c|c|c|c|c|c|c|}
\hline \multicolumn{9}{|c|}{ P ARSt (kg of P ha ${ }^{-1}$ day $^{-1}$ ) } \\
\hline Mono & $0.05(0.006) \mathrm{a}$ & 0.04 & 0.006 & 0.12 & 65.40 & 0.54 & -0.89 & $0.08^{*}$ \\
\hline IFP-I & $0.07(0.009) \mathrm{a}$ & 0.06 & 0.006 & 0.25 & 69.80 & 1.78 & 4.49 & $0.002^{* *}$ \\
\hline IFP-II & $0.06(0.006) \mathrm{a}$ & 0.06 & 0.00 & 0.14 & 52.70 & 1.03 & 1.65 & $0.11^{*}$ \\
\hline \multicolumn{9}{|c|}{ P ARLe (kg of $\mathrm{P} \mathrm{ha}^{-1}$ day $\left.^{-1}\right)$} \\
\hline Mono & $0.48(0.04)$ a & 0.47 & 0.15 & 1.27 & 48.04 & 1.26 & 3.02 & $0.19^{*}$ \\
\hline IFP-I & $0.21(0.02) \mathrm{b}$ & 0.21 & 0.05 & 0.57 & 55.98 & 1.52 & 3.75 & $0.01^{* *}$ \\
\hline IFP-II & $0.15(0.02) \mathrm{b}$ & 0.12 & 0.00 & 0.39 & 62.82 & 0.90 & 0.04 & $0.01^{* *}$ \\
\hline \multicolumn{9}{|c|}{ K GPRFor (kg of K ha-1 day $\left.^{-1}\right)$} \\
\hline Mono & $0.98(0.06) \mathrm{a}$ & 0.85 & 0.52 & 2.09 & 36.17 & 1.46 & 2.10 & $0.01^{* *}$ \\
\hline IFP-I & $0.89(0.09) \mathrm{a}$ & 0.84 & 0.18 & 2.31 & 54.53 & 1.24 & 2.21 & $0.22^{*}$ \\
\hline IFP-II & $0.63(0.06) \mathrm{b}$ & 0.57 & 0.00 & 1.50 & 54.00 & 0.90 & 0.71 & $0.18^{*}$ \\
\hline \multicolumn{9}{|c|}{ K ARSt $\left(\mathrm{kg}\right.$ of $\mathrm{K} \mathrm{ha}^{-1}$ day $\left.^{-1}\right)$} \\
\hline Mono & $0.10(0.01) b$ & 0.09 & 0.01 & 0.35 & 69.70 & 1.52 & 4.13 & $0.35^{*}$ \\
\hline IFP-I & $0.21(0.02) \mathrm{a}$ & 0.20 & 0.02 & 0.65 & 62.50 & 1.26 & 2.68 & $0.22^{*}$ \\
\hline IFP-II & $0.18(0.02) \mathrm{a}$ & 0.18 & 0.00 & 0.43 & 49.90 & 0.68 & 0.83 & $0.37^{*}$ \\
\hline \multicolumn{9}{|c|}{ K ARLe $\left(\mathrm{kg}\right.$ of $\mathrm{K} \mathrm{ha}^{-1}$ day $\left.^{-1}\right)$} \\
\hline Mono & $0.71(0.05) \mathrm{a}$ & 0.64 & 0.36 & 1.45 & 41.31 & 1.11 & 0.64 & $0.005^{* *}$ \\
\hline IFP-I & $0.47(0.05) b$ & 0.44 & 0.09 & 1.33 & 60.00 & 1.41 & 2.65 & $0.004^{* *}$ \\
\hline IFP-II & $0.36(0.04) \mathrm{b}$ & 0.30 & 0.00 & 0.99 & 60.00 & 1.17 & 1.13 & $0.008^{* *}$ \\
\hline \multicolumn{9}{|c|}{ Ca GPRFor $\left(\mathrm{kg}\right.$ of Ca ha ${ }^{-1}$ day $\left.^{-1}\right)$} \\
\hline Mono & $0.05(0.003) \mathrm{a}$ & 0.04 & 0.03 & 0.09 & 34.43 & 1.45 & 1.80 & $0.005^{* *}$ \\
\hline IFP-I & $0.03(0003) b$ & 0.03 & 0.007 & 0.08 & 52.60 & 1.10 & 1.92 & $0.35^{*}$ \\
\hline IFP-II & $0.02(0.002) \mathrm{c}$ & 0.02 & 0.00 & 0.05 & 55.56 & 0.78 & 0.28 & $0.27^{*}$ \\
\hline \multicolumn{9}{|c|}{ Ca ARSt $\left(\mathrm{kg}\right.$ of Ca ha ${ }^{-1}$ day $\left.^{-1}\right)$} \\
\hline Mono & $0.003(0.0004) \mathrm{a}$ & 0.003 & 0.0008 & 0.01 & 60.80 & 0.84 & 0.38 & $0.33^{*}$ \\
\hline IFP-I & $0.005(0.0006) \mathrm{a}$ & 0.005 & 0.0005 & 0.02 & 62.50 & 1.10 & 1.71 & $0.18^{*}$ \\
\hline IFP-II & $0.005(0.0005) \mathrm{a}$ & 0.004 & 0.00 & 0.01 & 58.90 & 1.09 & 1.44 & $0.41^{*}$ \\
\hline \multicolumn{9}{|c|}{ Ca ARLe (kg of Ca ha-1 day $^{-1}$ ) } \\
\hline Mono & $0.03(0.002) \mathrm{a}$ & 0.03 & 0.01 & 0.06 & 38.97 & 0.49 & -0.28 & $0.04^{* *}$ \\
\hline IFP-I & $0.02(0.002) b$ & 0.02 & 0.004 & 0.06 & 60.20 & 1.25 & 2.08 & $0.42^{*}$ \\
\hline IFP-II & $0.01(0.002) \mathrm{c}$ & 0.01 & 0.00 & 0.04 & 60.37 & 0.96 & 0.48 & $0.02^{* *}$ \\
\hline \multicolumn{9}{|c|}{ Mg GPRFor $\left(\mathrm{kg}\right.$ of $\mathrm{Mg} \mathrm{ha}^{-1}$ day $\left.^{-1}\right)$} \\
\hline Mono & $0.14(0.008) \mathrm{a}$ & 0.14 & 0.08 & 0.25 & 32.16 & 0.86 & 0.15 & $0.03^{* *}$ \\
\hline IFP-I & $0.11(0.01) b$ & 0.11 & 0.03 & 0.28 & 49.77 & 1.03 & 1.87 & $0.11^{*}$ \\
\hline IFP-II & $0.07(0.006) \mathrm{c}$ & 0.06 & 0.00 & 0.13 & 46.93 & 0.34 & -0.41 & $0.26^{*}$ \\
\hline \multicolumn{9}{|c|}{ Mg ARSt kg of Mg ha-1 day $^{-1}$ ) } \\
\hline Mono & $0.01(0.001) b$ & 0.01 & 0.002 & 0.03 & 61.80 & 0.87 & 0.69 & $0.25^{*}$ \\
\hline IFP-I & $0.02(0.002) \mathrm{a}$ & 0.02 & 0.002 & 0.06 & 59.50 & 0.77 & 0.58 & $0.43^{*}$ \\
\hline IFP-II & $0.02(0.002) \mathrm{a}$ & 0.02 & 0.00 & 0.04 & 49.20 & 0.33 & -0.33 & $0.06^{*}$ \\
\hline \multicolumn{9}{|c|}{ Mg ARLe $\left(\mathrm{kg}\right.$ of Mg hä ${ }^{-1}$ day $\left.^{-1}\right)$} \\
\hline Mono & $0.13(0.009) \mathrm{a}$ & 0.12 & 0.06 & 0.25 & 38.41 & 0.72 & -0.44 & $0.07^{*}$ \\
\hline IFP-I & $0.09(0.009) \mathrm{b}$ & 0.09 & 0.02 & 0.25 & 54.64 & 1.38 & 3.42 & $0.006^{* *}$ \\
\hline IFP-II & $0.05(0.005) \mathrm{c}$ & 0.05 & 0.00 & 0.10 & 50.61 & 0.51 & -0.45 & $0.01^{* *}$ \\
\hline \multicolumn{9}{|c|}{ Shading (\%) } \\
\hline IFP-I & $57.90(5.09) \mathrm{b}$ & 65.02 & 1.93 & 92.57 & 49.80 & -0.53 & -0.97 & $0.21^{*}$ \\
\hline IFP-II & $71.81(4.54) \mathrm{a}$ & 83.49 & 2.15 & 95.17 & 35.78 & -1.41 & 1.16 & $9 \times 10^{-5 * *}$ \\
\hline
\end{tabular}

Means followed by the same letter in the column do not differ (5\% Kruskal-Wallis). Values in parentheses refer to the standard error of the mean. ${ }^{(1)}$ Med.: median; ${ }^{(2)}$ min: minimum, ${ }^{(3)}$ max: maximum, ${ }^{(4)} \mathrm{KS}$ : Kolmogorov-Smirnov normality test, $\left({ }^{*}\right)$ : significant at $5 \%,(* *)$ : non-significant. 
The application of the Kolmogorov-Smirnov normality test showed that the Mono and IFP-I areas were not normally distributed in 53 and $62 \%$ of the total cases studied, respectively. Note that in these areas, the skewness values were positive and high when compared to those of IFP area II. Vieira et al. (2010) observed that foliar nutrients of soybeans in no-till areas were normally distributed.

Following the classification criteria of the coefficient of variation (CV) proposed by Warrick and Nielsen (1980), the daily extraction of N, P, $\mathrm{K}$ and $\mathrm{Ca}$ in the biomass of the grass leaves was highly variable $(\mathrm{CV}>60 \%)$ in the IFP-I and IFPII areas, and the other variables showed average variability $(12<\mathrm{CV}<60 \%)$. It is noteworthy that the CV was greater in IFP-I and IFP-II compared to that of the Mono area. This higher incidence of high CV in the IFP-I and IFP-II areas may be due to variation in the shading conditions, which in turn changes the deposition and accumulation patterns of soil nutrients. Thus, different nutrient inputs and light alter the grass growth rates and nutrient extraction. According to Paciullo et al. (2011), in an agro-silvopastoral system, the arboreal component changes most pasture characteristics, depending on the distance to the row of trees.

Coefficients of variation lower than $35 \%$ indicate that the data set is homogeneous and that the average has meaning and may thus be representative of the location from which it was obtained. Datasets with a CV greater than 35\% are heterogeneous, and the average has little meaning, while in those with a CV greater than $65 \%$, the series is highly heterogeneous, and the average has no meaning (NOGUEIRA, 2007). Thus, the use of average values does not adequately represent the variables in the study areas, which can cause errors in distinguishing sites. Therefore, information about the spatial variability of the variables should be incorporated through spatial association studies (KRAVCHENKO et al., 2006), which would help to reduce the standard error of the mean estimates (CERRI et al., 2004; VIEIRA et al., 2010).

The results of the geostatistical analysis indicate that all the variables presented spatial dependence defined by an omnidirectional semivariogram adjusted to theoretical spherical, exponential or Gaussian models (Table 3). When studying morphological components of Marandu grass in places with different levels of pasture degradation, Silva Neto et al. (2012) found that the values fitted spherical and exponential semivariogram models. Some studies have shown that mineral nutrient concentrations in the tissue of plants commonly fit spherical and exponential models (VIEIRA et al., 2010; LEÃO et al., 2010; CAVALCANTE et al., 2011; RODRIGUES JÚNIOR et al., 2011). The fitted models showed high coefficients of determination $\left(\mathrm{R}^{2}\right)$, ranging from 0.80 to 0.99 , and low residual sums of square $\left(\mathrm{SS}_{\mathrm{r}}\right)$. 
Table 3. Models and estimated parameters of semivariograms fitted to the values of extraction rates of mineral nutrients $(\mathrm{N}, \mathrm{P}, \mathrm{K}, \mathrm{Ca}$ and $\mathrm{Mg}$ ) by grass biomass due to the gross production rate of forage (GPRFor), forage accumulation (ARFor) and leaf accumulation (ARLe) and shading level in soil use systems based on Marandu grass monoculture (Mono) and in integrated Marandu grass forest-pasture systems with 50 and $70 \%$ shading (IFP-I and IFP-II, respectively).

Continue ...

\begin{tabular}{|c|c|c|c|c|c|c|c|c|c|}
\hline \multirow{2}{*}{ Location } & \multirow{2}{*}{ Model } & \multicolumn{8}{|c|}{ Parameter } \\
\hline & & $\mathrm{C}_{0}{ }^{1}$ & $\mathrm{C}_{1}^{2}$ & $\mathrm{Ra}^{3}$ & $\mathrm{DSD}^{4}$ & Class & $\mathrm{R}^{2^{*}}$ & $\mathrm{SS}_{\mathrm{r}}^{5}$ & $\mathrm{AIC}^{6}$ \\
\hline \multicolumn{10}{|c|}{ N GPRFor (kg of $\mathrm{N} \mathrm{ha}^{-1}$ day $\left.^{-1}\right)$} \\
\hline Mono & Exponential & 0.04 & 0.08 & 16.42 & 66 & Moderate & 0.97 & $2 \times 10^{-4}$ & -91.80 \\
\hline IFP-I & Exponential & 0.19 & 0.65 & 64.64 & 77 & Strong & 0.98 & $1 \times 10^{-3}$ & -58.89 \\
\hline IFP-II & Spherical & 0.03 & 0.23 & 29.92 & 88 & Strong & 0.90 & $2 \times 10^{-3}$ & -49.27 \\
\hline \multicolumn{10}{|c|}{ N ARSt $\left(\mathrm{kg}\right.$ of $\mathrm{N} \mathrm{ha}^{-1}$ day $\left.^{-1}\right)$} \\
\hline Mono & Spherical & 0.00 & 0.001 & 52.00 & 90 & Strong & 0.98 & $3 \times 10^{-8}$ & -181.60 \\
\hline IFP-I & Spherical & 0.00 & 0.005 & 40.46 & 90 & Strong & 0.99 & $1 \times 10^{-7}$ & -148.00 \\
\hline IFP-II & Gaussian & 0.0004 & 0.006 & 27.32 & 94 & Strong & 0.97 & $1 \times 10^{-6}$ & -145.80 \\
\hline \multicolumn{10}{|c|}{ N ARLe $\left(\mathrm{kg}\right.$ of $\mathrm{N} \mathrm{ha}^{-1}$ day $\left.^{-1}\right)$} \\
\hline Mono & Gaussian & 0.12 & 0.09 & 14.63 & 43 & Moderate & 0.96 & $2 \times 10^{-4}$ & -79.62 \\
\hline IFP-I & Exponential & 0.13 & 0.57 & 39.06 & 82 & Strong & 0.99 & $6 \times 10^{-4}$ & -66.36 \\
\hline IFP-II & Spherical & 0.02 & 0.22 & 29.36 & 93 & Strong & 0.87 & $3 \times 10^{-3}$ & -47.32 \\
\hline \multicolumn{10}{|c|}{ P GPRFor (kg of P ha-1 day $\left.^{-1}\right)$} \\
\hline Mono & Spherical & 0.006 & 0.04 & 26.00 & 86 & Strong & 0.87 & $9 \times 10^{-5}$ & -89.21 \\
\hline IFP-I & Exponential & 0.01 & 0.04 & 53.93 & 73 & Moderate & 0.99 & $4 \times 10^{-6}$ & -121.00 \\
\hline IFP-II & Spherical & 0.003 & 0.01 & 34.38 & 82 & Strong & 0.95 & $5 \times 10^{-5}$ & -115.00 \\
\hline \multicolumn{10}{|c|}{ P ARSt $\left(\mathrm{kg}\right.$ of $\mathrm{P} \mathrm{ha}^{-1}$ day $\left.^{-1}\right)$} \\
\hline Mono & Spherical & 0.00 & 0.0007 & 47.00 & 90 & Strong & 0.97 & $2 \times 10^{-8}$ & -184.00 \\
\hline IFP-I & Spherical & 0.0008 & 0.0006 & 42.53 & 87 & Strong & 0.99 & $3 \times 10^{-8}$ & -199.20 \\
\hline IFP-II & Spherical & 0.00 & 0.0005 & 50.01 & 90 & Strong & 0.98 & $4 \times 10^{-9}$ & -196.40 \\
\hline \multicolumn{10}{|c|}{ PARLe $\left(\mathrm{kg}\right.$ of $\mathrm{P} \mathrm{ha}^{-1}$ day $\left.^{-1}\right)$} \\
\hline Mono & Spherical & 0.01 & 0.03 & 25.58 & 72 & Moderate & 0.86 & $7 \times 10^{-5}$ & -91.65 \\
\hline IFP-I & Spherical & 0.005 & 0.01 & 52.35 & 71 & Moderate & 0.99 & $1 \times 10^{-6}$ & -132.30 \\
\hline IFP-II & Spherical & $8 \times 10^{-3}$ & 0.01 & 31.75 & 92 & Strong & 0.93 & $4 \times 10^{-6}$ & -117.80 \\
\hline \multicolumn{10}{|c|}{ K GPRFor $\left(\mathrm{kg}\right.$ of $\mathrm{K} \mathrm{ha}^{-1}$ day $\left.^{-1}\right)$} \\
\hline Mono & Spherical & 0.04 & 0.22 & 92.31 & 83 & Strong & 0.98 & $3 \times 10^{-4}$ & -90.23 \\
\hline IFP-I & Exponential & 0.11 & 0.73 & 131.90 & 86 & Strong & 0.99 & $3 \times 10^{-3}$ & -69.76 \\
\hline IFP-II & Spherical & 0.03 & 0.11 & 33.04 & 77 & Strong & 0.95 & $2 \times 10^{-4}$ & -71.63 \\
\hline \multicolumn{10}{|c|}{ K ARSt $\left(\mathrm{kg}\right.$ of K ha ${ }^{-1}$ day $\left.^{-1}\right)$} \\
\hline Mono & Spherical & 0.00 & 0.003 & 54.00 & 90 & Strong & 0.98 & $2 \times 10^{-7}$ & -155.40 \\
\hline IFP-I & Spherical & 0.00 & 0.008 & 48.32 & 90 & Strong & 0.99 & $3 \times 10^{-7}$ & -141.60 \\
\hline IFP-II & Spherical & 0.00 & 0.004 & 48.27 & 90 & Strong & 0.98 & $2 \times 10^{-7}$ & -151.00 \\
\hline \multicolumn{10}{|c|}{ K ARLe $\left(\mathrm{kg}\right.$ of $\mathrm{K} \mathrm{ha}^{-1}$ day $\left.^{-1}\right)$} \\
\hline Mono & Exponential & 0.04 & 0.16 & 70.00 & 80 & Strong & 0.94 & $1 \times 10^{-4}$ & -93.61 \\
\hline IFP-I & Exponential & 0.03 & 0.11 & 37.70 & 78 & Strong & 0.99 & $2 \times 10^{-5}$ & -98.23 \\
\hline IFP-II & Spherical & 0.01 & 0.04 & 28.95 & 74 & Moderate & 0.88 & $9 \times 10^{-5}$ & -83.95 \\
\hline \multicolumn{10}{|c|}{ Ca GPRFor $\left(\mathrm{kg}\right.$ of Ca ha ${ }^{-1}$ day $\left.^{-1}\right)$} \\
\hline Mono & Exponential & $1 \times 10^{-3}$ & $5 \times 10^{-3}$ & 55.53 & 82 & Strong & 0.95 & $3 \times 10^{-9}$ & -225.70 \\
\hline IFP-I & Exponential & $1 \times 10^{-3}$ & $3 \times 10^{-3}$ & 37.14 & 70 & Moderate & 0.97 & $9 \times 10^{-10}$ & -215.70 \\
\hline IFP-II & Spherical & $4 \times 10^{-4}$ & $1 \times 10^{-3}$ & 38.59 & 78 & Strong & 0.97 & $2 \times 10^{-10}$ & -230.30 \\
\hline
\end{tabular}


Continuation

\begin{tabular}{|c|c|c|c|c|c|c|c|c|c|}
\hline \multicolumn{10}{|c|}{ Ca ARSt (kg of Ca ha ${ }^{-1}$ day $\left.^{-1}\right)$} \\
\hline Mono & Spherical & 0.00 & $3 \times 10^{-5}$ & 54.00 & 90 & Strong & 0.97 & $2 \times 10^{-13}$ & -306.80 \\
\hline IFP-I & Spherical & 0.00 & $4 \times 10^{-5}$ & 48.00 & 90 & Strong & 0.94 & $8 \times 10^{-13}$ & -286.10 \\
\hline IFP-II & Spherical & 0.00 & $4 \times 10^{-5}$ & 49.00 & 90 & Strong & 0.97 & $6 \times 10^{-13}$ & -294.10 \\
\hline \multicolumn{10}{|c|}{ Ca ARLe ( $\mathrm{kg}$ of $\left.\mathrm{Ca} \mathrm{ha-1} \mathrm{day}^{-1}\right)$} \\
\hline Mono & Gaussian & $1 \times 10^{-3}$ & $5 \times 10^{-4}$ & 26.35 & 27 & Moderate & 0.80 & $4 \times 10^{-10}$ & -41.91 \\
\hline IFP-I & Spherical & $5 \times 10^{-4}$ & $2 \times 10^{-3}$ & 40.49 & 81 & Strong & 0.98 & $7 \times 10^{-10}$ & -218.50 \\
\hline IFP-II & Spherical & $3 \times 10^{-4}$ & $8 \times 10^{-4}$ & 43.83 & 74 & Moderate & 0.97 & $1 \times 10^{-10}$ & -247.10 \\
\hline \multicolumn{10}{|c|}{ Mg GPRFor $\left(\mathrm{kg}\right.$ of $\left.\mathrm{Mg} \mathrm{ha}^{-1} \mathrm{day}^{-1}\right)$} \\
\hline Mono & Spherical & 0.001 & 0.002 & 100.00 & 64 & Moderate & 0.96 & $6 \times 10^{-8}$ & -180.20 \\
\hline IFP-I & Exponential & 0.001 & 0.003 & 16.74 & 69 & Moderate & 0.96 & $1 \times 10^{-7}$ & -163.00 \\
\hline IFP-II & Spherical & $2 \times 10^{-3}$ & 0.001 & 35.28 & 81 & Strong & 0.97 & $2 \times 10^{-8}$ & \\
\hline \multicolumn{10}{|c|}{$\operatorname{Mg}$ ARSt $\left(\mathrm{kg}\right.$ of Mg ha ${ }^{-1}$ day $\left.^{-1}\right)$} \\
\hline Mono & Spherical & 0.00 & 0.00003 & 54.00 & 90 & Strong & 0.98 & $4 \times 10^{-11}$ & -252.70 \\
\hline IFP-I & Spherical & 0.00 & 0.00005 & 31.97 & 90 & Strong & 0.98 & $5 \times 10^{-11}$ & -232.90 \\
\hline IFP-II & Spherical & 0.00 & 0.00005 & 59.30 & 90 & Strong & 0.96 & $8 \times 10^{-11}$ & -241.40 \\
\hline \multicolumn{10}{|c|}{ Mg ARLe $\left(\mathrm{kg}\right.$ of Mg ha ${ }^{-1}$ day $\left.^{-1}\right)$} \\
\hline Mono & Spherical & 0.002 & 0.001 & 55.40 & 36 & Moderate & 0.96 & $2 \times 10^{-8}$ & -173.20 \\
\hline IFP-I & Spherical & 0.001 & 0.002 & 44.39 & 59 & Moderate & 0.98 & $3 \times 10^{-8}$ & -172.90 \\
\hline IFP-II & Spherical & $2 \times 10^{-3}$ & $8 \times 10^{-3}$ & 34.78 & 83 & Strong & 0.98 & $1 \times 10^{-8}$ & -196.10 \\
\hline \multicolumn{10}{|c|}{ Shading (\%) } \\
\hline IFP- I & Spherical & 0.00 & 655.00 & 57.00 & 100 & Strong & 0.98 & 14540 & 116.1 \\
\hline IFP-II & Spherical & 0.00 & 393.30 & 64.57 & 100 & Strong & 0.99 & 613 & 97.89 \\
\hline
\end{tabular}

${ }^{(1)} \mathrm{C}_{0}$ : nugget effect; ${ }^{\left({ }^{2}\right)} \mathrm{C}_{1}$ : sill; ${ }^{(3)} \mathrm{Ra}$ : range; ${ }^{(4)} \mathrm{DSD}$ : degree of spatial dependence; ${ }^{(5)} \mathrm{SS}_{\mathrm{r}}$ : square sum of residuals, ${ }^{(6)} \mathrm{AIC}$ : Akaike criteria, ${ }^{(*)} \mathrm{R}^{2}$ : coefficient of determination.

The values of the DSD in most locations and variables were strong. This result indicates that the component related to random variation $\left(\mathrm{C}_{0}\right)$ is much smaller than the component associated with the structured variation $\left(\mathrm{C}_{1}\right)$. Therefore, it is expected that the phenomenon described by the models fitted to the semivariogram can be represented more accurately by interpolation with ordinary kriging (VIEIRA et al., 2010). Identifying these areas can assist in generating management techniques to better leverage the benefits of silvopastoral systems deployed in thinned forests.

The lower range values were found in the variables that express the extraction of $\mathrm{N}$ and $\mathrm{P}$ in the Mono area, ranging from 14.63 to 26.00 $\mathrm{m}$. The largest ranges (from 52.35 to $131.90 \mathrm{~m}$ ) occurred mainly in the Mono (K ARFor, K ARLe,
$\mathrm{Ca}$ GPRFor, $\mathrm{Ca}$ ARFor, $\mathrm{Mg}$ GPRFor, $\mathrm{Mg}$ ARFor and Mg ARLe) and IFP-I sites (N GPRFor, N ARFor, N ARLe, P GPRFor, P ARFor, P ARLe and K GPRFor). Therefore, the sampling grid used was sufficient to express the spatial variability of the variables.

Thus, the results are suitable to characterize the phenomena at the investigated sites. Accordingly, ordinary kriging with the semivariogram models (fitted to each environment) was used to interpolate the variable values at the unsampled points. Finally, it was possible to perform the PCA using the generated values.

After PCA, two components were extracted with eigenvalues greater or close to 1 that cumulatively explain $89.59,97.74$ and $96.67 \%$ of the total variability of the data areas of Mono, 
IFP-I and IFP-II, respectively (Table 4). Thus, the 15 original variables in the Mono area and 16 variables for the other areas were represented by two components of the original set with a loss of explanation of $10.41,2.26$ and $3.33 \%$ in the Mono, IFP-I and IFP-II sites, respectively.

Table 4. Summary of principal components analysis.

\begin{tabular}{|c|c|c|c|c|c|c|}
\hline \multirow{4}{*}{ Variance Component } & \multicolumn{6}{|c|}{ Local } \\
\hline & \multicolumn{2}{|c|}{ Mono $^{1}$} & \multicolumn{2}{|c|}{ IFP-I ${ }^{2}$} & \multicolumn{2}{|c|}{ IFP-II ${ }^{3}$} \\
\hline & \multicolumn{6}{|c|}{ Principal Component } \\
\hline & $1^{\circ}$ & $2^{\circ}$ & $1^{\mathrm{o}}$ & $2^{\circ}$ & $1^{\mathrm{o}}$ & $2^{\circ}$ \\
\hline Eigenvalue & 8.91 & 3.48 & 13.59 & 1.33 & 13.75 & 1.21 \\
\hline Variance (\%) & 59.40 & 23.19 & 84.95 & 8.29 & 85.93 & 7.54 \\
\hline Accumulated variance & 59.40 & 82.59 & 84.95 & 93.24 & 85.93 & 93.47 \\
\hline
\end{tabular}

(1) Mono: Marandu grass monoculture, ${ }^{(2)}$ IFP-I: Integrated Marandu grass forest-pasture system with $50 \%$ shade, ${ }^{(3)}$ IFP-II: Integrated Marandu grass forest-pasture system with $70 \%$ shade.

The first principal component alone represented $76.64,91.52$ and $90.80 \%$ of the total variability of the data in the Mono, IFP-I and IFP-II areas, respectively (Table 5). In the Mono area, the variables that showed the strongest positive correlations $(<0.90)$ with this component were $\mathrm{N}$, $\mathrm{K}$ and $\mathrm{Ca}$ extraction rates. In the IFP-I and IFP-II areas, only the shading level had a low, negative correlation with the first component. Thus, these results indicate that in the IFP sites, the level of shading and nutrient extraction capacity by grass biomass will contribute to the dissimilarity of the management zones, whereas in the Marandu grass monoculture, just a few nutrient extraction rates would define the different zones. It should be noted that the first principal component is always the most important (GUEDES et al., 2006) and that its variables have higher weights in the classification.

Table 5. Correlation between the original variables and the principal components of mineral nutrient extraction rates $(\mathrm{N}, \mathrm{P}, \mathrm{K}, \mathrm{Ca}$ and $\mathrm{Mg}$ ) by grass biomass in relation to the gross production rate of forage (GPRFor), forage accumulation (ARFor) and leaf accumulation (ARLe) and shading level in soil use systems based on Marandu grass monoculture (Mono) and in integrated Marandu grass forest-pasture systems with 50 and $70 \%$ shading (IFP-I and IFP-II, respectively).

Continue ...

\begin{tabular}{|c|c|c|c|c|c|c|}
\hline \multirow{4}{*}{ Variable } & \multicolumn{6}{|c|}{ Location } \\
\hline & \multicolumn{2}{|c|}{ Mono } & \multicolumn{2}{|c|}{ IFP-I } & \multicolumn{2}{|c|}{ IFP-II } \\
\hline & \multicolumn{6}{|c|}{ Principal Component } \\
\hline & $1^{\mathrm{o}}$ & $2^{\circ}$ & $1^{\circ}$ & $2^{\circ}$ & $1^{\mathrm{o}}$ & $2^{\circ}$ \\
\hline N GPRFor & 0.94 & -0.25 & 0.97 & -0.16 & 0.96 & 0.24 \\
\hline N ARSt & 0.55 & 0.80 & 0.92 & 0.35 & 0.89 & -0.20 \\
\hline N ARLe & 0.80 & -0.42 & 0.97 & -0.15 & 0.94 & 0.30 \\
\hline P GPRFor & 0.82 & -0.30 & 0.96 & -0.25 & 0.96 & 0.10 \\
\hline P ARSt & 0.82 & -0.37 & 0.96 & -0.01 & 0.94 & -0.29 \\
\hline P ARLe & 0.82 & -0.37 & 0.97 & -0.01 & 0.95 & 0.20 \\
\hline K GPRFor & 0.87 & 0.11 & 0.96 & -0.07 & 0.98 & 0.12 \\
\hline
\end{tabular}


Continuation

\begin{tabular}{lcccccc} 
K ARSt & 0.55 & $\mathbf{0 . 8 1}$ & $\mathbf{0 . 8 7}$ & 0.44 & $\mathbf{0 . 9 4}$ & -0.26 \\
K ARLe & $\mathbf{0 . 9 3}$ & 0.03 & $\mathbf{0 . 9 9}$ & -0.05 & $\mathbf{0 . 9 6}$ & 0.22 \\
Ca GPRFor & $\mathbf{0 . 9 1}$ & 0.05 & $\mathbf{0 . 9 8}$ & -0.10 & $\mathbf{0 . 9 9}$ & 0.04 \\
Ca ARSt & 0.44 & $\mathbf{0 . 8 5}$ & $\mathbf{0 . 8 9}$ & 0.13 & $\mathbf{0 . 9 4}$ & -0.29 \\
Ca ARLe & $\mathbf{0 . 7 3}$ & -0.23 & $\mathbf{0 . 9 6}$ & 0.06 & $\mathbf{0 . 9 7}$ & -0.002 \\
Mg GPRFor & $\mathbf{0 . 8 6}$ & -0.02 & $\mathbf{0 . 9 8}$ & -0.07 & $\mathbf{0 . 9 5}$ & 0.18 \\
Mg ARSt & 0.47 & $\mathbf{0 . 8 4}$ & $\mathbf{0 . 8 5}$ & 0.36 & $\mathbf{0 . 9 1}$ & -0.25 \\
Mg ARLe & $\mathbf{0 . 8 0}$ & -0.26 & $\mathbf{0 . 9 8}$ & -0.05 & $\mathbf{0 . 9 2}$ & 0.26 \\
Shade & - & - & -0.32 & $\mathbf{0 . 8 5}$ & -0.54 & $\mathbf{0 . 7 1}$ \\
\hline
\end{tabular}

Numbers in bold highlight the variables strongly correlated $(>0.70)$ with the principal components.

The second main component represented only $12.95,6.23$ and $5.87 \%$ of the total variance of the data in the Mono, IFP-I and IFP-II areas, respectively (Table 5). In the Mono area, this component had a higher correlation with the $\mathrm{P}$ extraction rate (Table 5). This new variable grouped areas by the similarity in their ability to extract P. In contrast, the treetopshading levels will contribute to classify the zones in IFP-I and IFP-II areas.

Based on these new PCA variables, management zones were defined that can cause different responses to the production system, depending on the variables investigated. For this purpose, the non-hierarchical clustering technique fuzzy k-means was used, which is an iterative method that has a greater capacity for analysis of larger data sets (MINGOTI, 2007). The appropriate number of classes was determined using FPI and MPE values as a function of the number of classes grouping the data in each area (Figure 2a, 2b, 2c). From the results of the FPI and MPE indices shown in Figure 2 , the optimal number of management area classes would be 5, 2 and 2 in the Mono, IFP-I and IFP-II areas, respectively.

Figure 2. FPI (--) and MPE (----) index values in relation to class numbers in the areas of Marandu grass monoculture (a), and in integrated Marandu grass forest-pasture systems with 50 and $70 \%$ shading (b and c, respectively).

(a)

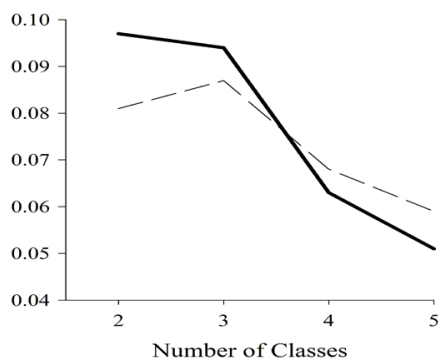

(b)

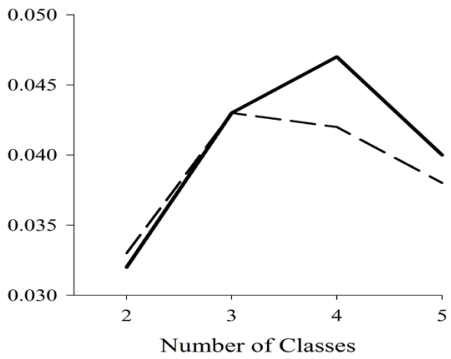

(c)

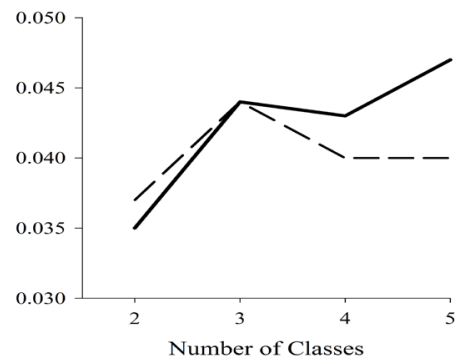

Interpolation followed the definition of the optimal number of classes. Interpolations were performed on the basis of the participation of each individual $i$ in class $k$ using natural neighbors interpolation (Figure 3). Map analysis showed that the classes generated by the fuzzy k-means logic were grouped mainly by shading level in the IFP-I and II areas. Grouping in the Mono area revealed a clear link between the classes and the N, K and Ca content. 
Table 6 shows the ANOVA results between the generated classes. It was observed that in the Mono area, larger $\mathrm{N}$ and $\mathrm{P}$ extraction rates were observed in class $\mathrm{A}$, and higher extraction rates of the other nutrients $(\mathrm{K}, \mathrm{Ca}$ and $\mathrm{Mg}$ ) were observed in class $\mathrm{D}$.
The smallest extraction generally occurred in places grouped in class $\mathrm{B}$. In classes $\mathrm{C}$ and $\mathrm{E}$, intermediate nutrient export rates by the biomass of Marandu grass were found. In the IFP-I and IFP-II sites, low nutrient uptake occurred in places with higher levels of shading.

Figure 3. Contour maps of management classes in the areas of Marandu grass monoculture (Mono) and in integrated Marandu grass forest-pasture systems with 50 and 70\% shading (IFP-I and IFP-II, respectively).
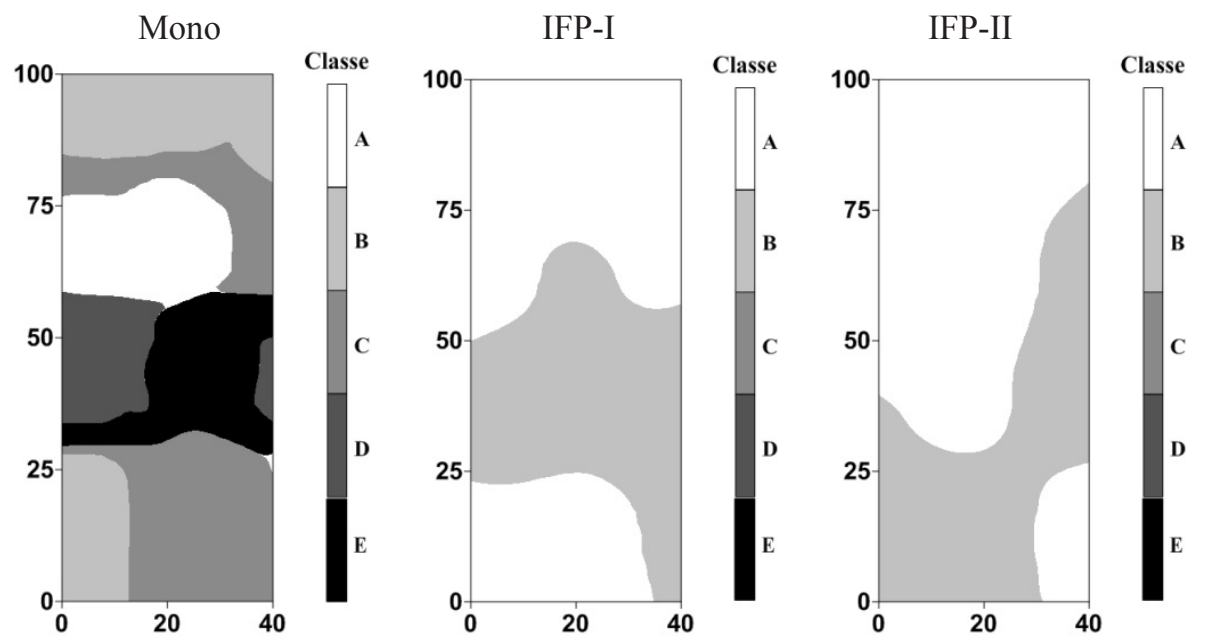

Table 6. Nutrient extraction rates (N, P, K, Ca and Mg) by the Marandu grass biomass in relation to the gross production rate of forage (GPRFor), forage accumulation (ARFor) and leaf accumulation (ARLe) and shading level in the management classes generated.

Continue ...

\begin{tabular}{|c|c|c|c|c|c|c|c|c|c|}
\hline \multirow{4}{*}{ Variable } & \multicolumn{9}{|c|}{ Location } \\
\hline & \multicolumn{5}{|c|}{ Mono $^{1}$} & \multicolumn{2}{|c|}{ IFP-I $^{2}$} & \multicolumn{2}{|c|}{ IFP-II $^{3}$} \\
\hline & \multicolumn{9}{|c|}{ Class } \\
\hline & A & B & $\mathrm{C}$ & $\mathrm{D}$ & $\mathrm{E}$ & A & B & A & B \\
\hline N GPRFor & $1.09 \mathrm{c}$ & $1.31 \mathrm{~b}$ & $0.84 \mathrm{~d}$ & $1.09 \mathrm{c}$ & $1.35 \mathrm{a}$ & $1.49 \mathrm{a}$ & $1.16 \mathrm{~b}$ & $1.14 \mathrm{a}$ & $0.84 \mathrm{~b}$ \\
\hline N ARSt & $0.05 \mathrm{~d}$ & $0.09 \mathrm{a}$ & $0.05 \mathrm{~d}$ & $0.08 \mathrm{~b}$ & $0.07 \mathrm{c}$ & $0.21 \mathrm{a}$ & $0.21 \mathrm{a}$ & $0.22 \mathrm{a}$ & $0.17 \mathrm{~b}$ \\
\hline N ARLe & $1.21 \mathrm{c}$ & $1.38 \mathrm{~b}$ & $0.94 \mathrm{e}$ & $1.11 \mathrm{~d}$ & $1.61 \mathrm{a}$ & $1.34 \mathrm{a}$ & $1.01 \mathrm{~b}$ & $0.99 \mathrm{a}$ & $0.73 \mathrm{~b}$ \\
\hline P GPRFor & $0.59 \mathrm{c}$ & $0.62 \mathrm{~b}$ & $0.34 \mathrm{e}$ & $0.48 \mathrm{~d}$ & $0.79 \mathrm{a}$ & $0.39 \mathrm{a}$ & $0.29 \mathrm{~b}$ & $0.30 \mathrm{a}$ & $0.19 \mathrm{~b}$ \\
\hline P ARSt & $0.53 \mathrm{c}$ & $0.57 \mathrm{~b}$ & $0.31 \mathrm{e}$ & $0.43 \mathrm{~d}$ & $0.72 \mathrm{a}$ & $0.08 \mathrm{a}$ & $0.07 \mathrm{~b}$ & $0.07 \mathrm{a}$ & $0.05 \mathrm{~b}$ \\
\hline PARLe & $0.53 \mathrm{c}$ & $0.56 \mathrm{~b}$ & $0.30 \mathrm{e}$ & $0.43 \mathrm{~d}$ & $0.71 \mathrm{a}$ & $0.25 \mathrm{a}$ & $0.21 \mathrm{~b}$ & $0.22 \mathrm{a}$ & $0.14 \mathrm{~b}$ \\
\hline K GPRFor & $0.89 \mathrm{~d}$ & $1.45 \mathrm{a}$ & $0.72 \mathrm{e}$ & $1.18 \mathrm{~b}$ & $1.06 \mathrm{c}$ & $1.11 \mathrm{a}$ & $0.91 \mathrm{~b}$ & $0.85 \mathrm{a}$ & $0.59 \mathrm{~b}$ \\
\hline K ARSt & $0.06 \mathrm{e}$ & $0.14 \mathrm{a}$ & $0.07 \mathrm{~d}$ & $0.12 b$ & $0.09 \mathrm{c}$ & $0.22 \mathrm{~b}$ & $0.23 \mathrm{a}$ & $0.22 \mathrm{a}$ & $0.16 \mathrm{~b}$ \\
\hline K ARLe & $0.64 \mathrm{~d}$ & $1.01 \mathrm{a}$ & $0.53 \mathrm{e}$ & $0.81 \mathrm{c}$ & $0.86 \mathrm{~b}$ & $0.59 \mathrm{a}$ & $0.48 \mathrm{~b}$ & $0.48 \mathrm{a}$ & $0.35 \mathrm{~b}$ \\
\hline Ca GPRFor & $0.045 \mathrm{~d}$ & $0.070 \mathrm{a}$ & $0.038 \mathrm{e}$ & $0.054 \mathrm{c}$ & $0.057 \mathrm{~b}$ & $0.04 \mathrm{a}$ & $0.03 \mathrm{~b}$ & $0.03 \mathrm{a}$ & $0.02 \mathrm{~b}$ \\
\hline $\mathrm{Ca}$ ARSt & $0.003 \mathrm{e}$ & $0.005 \mathrm{a}$ & $0.0035 \mathrm{~d}$ & $0.004 \mathrm{~b}$ & $0.0037 \mathrm{c}$ & $0.006 \mathrm{a}$ & $0.005 \mathrm{~b}$ & $0.006 \mathrm{a}$ & $0.004 \mathrm{~b}$ \\
\hline $\mathrm{Ca}$ ARLe & $0.033 \mathrm{~d}$ & $0.04 \mathrm{a}$ & $0.029 \mathrm{e}$ & $0.036 \mathrm{~b}$ & $0.035 \mathrm{c}$ & $0.03 \mathrm{a}$ & $0.02 \mathrm{~b}$ & $0.02 \mathrm{a}$ & $0.01 \mathrm{~b}$ \\
\hline
\end{tabular}




\begin{tabular}{lccccccccc}
\hline Mg GPRFor & $0.151 \mathrm{c}$ & $0.181 \mathrm{a}$ & $0.113 \mathrm{~d}$ & $0.158 \mathrm{~b}$ & $0.152 \mathrm{c}$ & $0.14 \mathrm{a}$ & $0.11 \mathrm{~b}$ & $0.09 \mathrm{a}$ & $0.07 \mathrm{~b}$ \\
Mg ARSt & $0.009 \mathrm{e}$ & $0.017 \mathrm{a}$ & $0.010 \mathrm{~d}$ & $0.014 \mathrm{~b}$ & $0.012 \mathrm{c}$ & $0.025 \mathrm{a}$ & $0.024 \mathrm{~b}$ & $0.022 \mathrm{a}$ & $0.016 \mathrm{~b}$ \\
Mg ARLe & $0.15 \mathrm{~b}$ & $0.17 \mathrm{a}$ & $0.11 \mathrm{~d}$ & $0.14 \mathrm{c}$ & $0.15 \mathrm{~b}$ & $0.11 \mathrm{a}$ & $0.09 \mathrm{~b}$ & $0.06 \mathrm{a}$ & $0.05 \mathrm{~b}$ \\
Shade & - & - & - & - & - & $35.14 \mathrm{~b}$ & $71.88 \mathrm{~b}$ & $51.82 \mathrm{~b}$ & \\
\hline
\end{tabular}

(1) Mono: Marandu grass monoculture (2) IFP-I: Integrated Marandu grass forest-pasture system with $50 \%$ shading, (3) IFP-II: Integrated Marandu grass forest-pasture system with $70 \%$ shading

\section{Conclusions}

Extraction zones of mineral nutrients by Brachiaria brizantha cv. Marandu biomass were defined using geostatistical techniques, PCA and non-hierarchical fuzzy k-means clustering. Thus, the use of these procedures is viable for the definition and delimitation of homogenous zones within and between the pasture production systems studied.

\section{Acknowledgements}

The authors would like to thank "Conselho Nacional de Desenvolvimento Científico e Tecnológico - CNPq" and "Coordenação de Aperfeiçoamento de Pessoal de Nível Superior CAPES" for the support and scholarships provided.

\section{References}

ANDRADE, C. M. S.; VALENTIM, J. F.; CARNEIRO, J. C.; VAZ, F. A. Crescimento de gramíneas e leguminosas forrageiras tropicais sob sombreamento. Pesquisa Agropecuária Brasileira, Brasília, v. 39, n. 3, p. 263-270, 2004.

CARVALHO, M. M.; BOTREL, M. A. Arborização de pastagens: um caminha para sustentabilidade de sistemas de produção animal a pasto. In: FORRAGICULTURA E PASTAGENS: TEMAS EM EVIDENCIA, 2002, Lavras. Anais... Lavras: Editora UFLA, 2002. v. 3, p. 31-76.

CAVALCANTE, E, G. S.; ALVES, M. C.; SOUZA, Z. M.; PEREIRA, G. T. Variabilidade espacial de atributos físicos do solo sob diferentes usos e manejos. Revista Brasileira de Engenharia Agrícola e Ambiental, Campina Grande, v. 15, n. 3, p. 237-243, 2011.

CERRI, C. E. P.; CERRI, C. C.; PAUSTIAN, K.; BERNOUX, M.; MELLILO, J. M. Combining soil C and $\mathrm{N}$ spatial variability and modeling approaches for measuring and monitoring soil carbon sequestration. Environmental Management, New York, v. 33, p. S274-S288, 2004. Supplement 1.

DIAS-FILHO, M. B. Photosynthetic light response of the $\mathrm{C} 4$ grasses Brachiaria brizantha and B. humidicola under shade. Scientia Agricola, Piracicaba, v. 59, n. 1, p. 65-68, 2002.

EMPRESA BRASILEIRA DE PESQUISA AGROPECUÁRIA-EMBRAPA. Manual de laboratórios: solo, água, nutrição vegetal, nutrição animal e alimentos. São Carlos: Embrapa Pecuária Sudeste, 2005. 334 p.

Sistema brasileiro de classificação de solos. Brasília: Embrapa Produção de Informação, 2006. 306 p.

GUEDES, M. C.; ANDRADE, C. A.; POGGIANI, F.; MATTIAZZO, M. E. Propriedades químicas do solo e nutrição do eucalipto em função da aplicação de lodo de esgoto. Revista Brasileira de Ciência do Solo, Viçosa, MG, v. 30, n. 2, p. 267-280, 2006.

KRAVCHENKO, A. N.; ROBERTSON, G. P.; SNAP, S. S.; SMUCKER, A. J. M. Using information about spatial variability to improve estimates of total soil carbon. Agronomy Journal, Madison, v. 98, n. 3, p. 823-829, 2006.

LEÃO, M. G. A.; MARQUES JÚNIOR, J.; SOUZA, Z. M.; SIQUEIRA, D. S.; PEREIRA, G. T. O relevo na interpretação da variabilidade espacial dos teores de nutrientes em folhas de citros. Revista Brasileira de Engenharia Agrícola e Ambiental, Campina Grande, v. 14, n. 11, p. 1152-1159, 2010.

MARDIA, K. V.; KENT, J. T.; BIBBY, J. M. Multivariate analysis. London: Academic, 1979. 521 p.

MATHERON, G. Principles of geostatistics. Economic Geology, Littleton, v. 58, n. 8, p. 1246-1266, 1963.

MINGOTI, S. A. Análise de dados através de métodos de estatística multivariada: uma abordagem aplicada. Belo Horizonte: Editora UFMG, 2005. 297 p.

NEVES, C.M.N.; SILVA, M.L. N.; CURI, N.; MACEDO, R. L. G.; MOREIRA, F. M. de S.; D’ANDRÉA, A. F. Indicadores biológicos da qualidade do solo em sistema 
agrossilvipastoril no noroeste do Estado de Minas Gerais. Ciência e Agrotecnologia, Lavras, v. 33, n. 1, p. 105-112, 2009.

NOGUEIRA, M. C. S. Experimentação agronômica I. Piracicaba: Universidade de São Paulo, 2007. 463 p.

PACIULLO, D. S. C.; CAMPOS, N. R.; GOMIDE, C. A. M.; CASTRO, C. R. T.; TAVELA, R. C.; ROSSIELLO, R. O. P. Crescimento de capim-braquiária influenciado pelo grau de sombreamento e pela estação do ano. Pesquisa Agropecuária Brasileira, Brasília, v. 43, n. 7, p. 917-923, 2008.

PACIULLO, D. S. C.; GOMIDE, C. A. M.; CASTRO, C. R. T.; FERNANDES, P. B.; MÜLLER, M. D.; PIRES, M. F. A.; FERNANDES, E. N.; XAVIER, D. F. Características produtivas e nutricionais do pasto em sistema agrossilvipastoril, conforme a distância das árvores. Pesquisa Agropecuária Brasileira, Brasília, v. 46, n. 10, p. 1176-1183, 2011.

PONTES, L. S.; NABINGER, C.; CARVALHO, P. C. F.; TRINDADE, J. K.; MONTARDO, D. P.; SANTOS, R. J. Variáveis morfogênicas e estruturais de azevém anual (Lolium multiflorum Lam.) manejado em diferentes alturas. Revista Brasileira de Zootecnia, Viçosa, MG, v. 32, n. 4, p. 814-820, 2003.

ROBERTSON, G. P. GS+: geostatistics for the environmental sciences - GS+ User's guide. Plainwell: [s.n.], 2008. $152 \mathrm{p}$.

RODRIGUES JÚNIOR, F. A.; VIEIRA, L. B.; QUEIROZ, D. M.; SANTOS, N. T. Geração de zonas de manejo para cafeicultura empregando-se sensor SPAD e análise foliar. Revista Brasileira de Engenharia Agrícola e Ambiental, Campina Grande, v. 15, n. 8, p. 778-787, 2011.
SILVA NETO, S. P.; SANTOS, A. C.; LIMA LEITE, R. L.; DIM, V. P.; NEVES NETO, D. N.; CRUZ, R. S. Dependência espacial em levantamentos do estoque de carbono em áreas de pastagens de Brachiaria brizantha cv. Marandu. Acta Amazônica, Manaus, v. 42, n. 4, p. 547-556, 2012.

SOUSA, L. F.; MAURÍCIO, R. M.; GONÇALVES, L. C.; SALIBA, E. O. S.; MOREIRA, G. R. Produtividade e valor nutritivo da Brachiaria brizantha cv. Marandu em um sistema silvipastoril. Arquivo Brasileiro de Medicina Veterinária e Zootecnia, Belo Horizonte, v. 59, n. 4, p. 1029-1037, 2007.

VIEIRA, S. R. Geoestatística em estudos de variabilidade espacial do solo. In: NOVAIS, R. F.; ALVAREZ, V. H.; SCHAEFER, C. E. G. R. (Ed.). Tópicos em ciência do solo. Viçosa, MG: Sociedade Brasileira de Ciência do Solo, 2000. v. 1, p. 1-53.

VIEIRA, S. R.; GUEDES FILHO, O.; CHIBA, M. K.; MELLIS, E. V.; DECHEN, S. C. F.; DE MARIA, I. C. Variabilidade espacial dos teores foliares de nutrientes e produtividade da soja em dois anos de cultivo em Latossolo Vermelho. Revista brasileira de Ciência do Solo, Viçosa, MG, v. 34, n. 5, p. 1503-1514, 2010.

WARRICK, A. W.; NIELSEN, D. R. Spatial variability of soil physical properties in the field. In: HILLEL, D. (Ed.). Application of soil physics. New York: Academic Press, 1980. p. 319-344.

XAVIER, D. F.; CARVALHO, M. M.; ALVIM, M. J.; BOTREL, M. A. Melhoramento da fertilidade do solo em pastagem de Brachiaria decumbens associada com leguminosas arbóreas. Pasturas Tropicales, Cali, v. 25, n. 1, p. 23-26, 2003. 
